(2) Open Access Full Text Article

\title{
Myopia in schoolchildren in a rural community in the State of Mexico, Mexico
}

This article was published in the following Dove Press journal:

Clinical Optometry

8 June 2016

Number of times this article has been viewed

\section{Omar Garcia-Lievanos \\ Leticia Sanchez-Gonzalez \\ Nadia Espinosa-Cruz \\ Luis A Hernandez-Flores \\ Leonel Salmeron-Leal Hector D Torres-Rodriguez}

Instituto Politecnico Nacional (IPN), Ex-Hacienda del Mayorazgo, Mexico City, Mexico
Correspondence: Omar Garcia-Lievanos Instituto Politecnico Nacional (IPN), Ex-Hacienda del Mayorazgo, Km 39.5 Carr Xochimilco-Oaxtepec, CP I2000, AP 5, Mexico City, Mexico

Tel +52 5557296000 ext 82339

Email ogarcial@ipn.mx
Purpose: This study sought to determine the prevalence of myopia in schoolchildren of a rural population in Mexico.

Methods: A cross-sectional study was conducted in 317 children between 6 and 12 years old. A complete refractive examination was performed, including static retinoscopy without cycloplegic agents. All procedures were conducted according to the Declaration of Helsinki.

Results: In total, 9.7\% (95\% CI: 13.07-6.52) of the examined children were myopic (spherical equivalent $\leq-0.50 \mathrm{D}), 4.4 \%$ (95\% CI: 6.66-2.14) presented astigmatism (cylinder $\leq-1.50 \mathrm{D})$, and 5.4\% (95\% CI: 7.89-2.91) presented hyperopia (spherical equivalent $\geq+0.50 \mathrm{D})$.

Conclusion: Additional research is required to assess the prevalence of refractive errors in rural areas in Mexico, to analyze the associated risk factors, and to implement appropriate eye care plans for this population.

Keywords: myopia, refractive errors, hyperopia, astigmatism

\section{Introduction}

The potential for a myopia epidemic has been described due to the increase in its prevalence in recent years. ${ }^{1-14}$ Various factors affect the prevalence of myopia, including age, ${ }^{4,8-13}$ ethnicity, ${ }^{14-17}$ the criteria for defining myopia and genetic, ${ }^{18-20}$ and environmental factors. ${ }^{5,6,17,21-23}$ The main environmental factors analyzed thus far include near work, ${ }^{16,17,21,23-25}$ outdoor activities, ${ }^{16,26-29}$ and population type (rural or urban). ${ }^{30-33}$

The change in the prevalence of myopia in each geographical zone is as follows: Pakistan, ${ }^{7} 36.5 \%$ in adults; Japan, ${ }^{8} 41.8 \%$ in adults; India, ${ }^{5,9} 28 \%$ and $34.6 \%$ in adults; Singapore, ${ }^{10} 30.7 \%$ in adults; Poland, ${ }^{11} 13.3 \%$ in children; Ireland, ${ }^{12} 2.8 \%$ and $17.7 \%$ increased from 6 and 7 years to 12 and 13 years; Hong Kong, ${ }^{13} 36.71 \%$ in children; and USA, ${ }^{14}$ the prevalence of myopia increased from 1971-1972 to 1999-2004. There are a few studies about the prevalence of myopia in Latin America, for example, Los Angeles Latino Eye Study reported a prevalence of myopia (spherical equivalent [SE] $\leq-1.00 \mathrm{D})$ of $16.8 \%$ in the worse eye from adults aged 40 years and older; ${ }^{34}$ in Brazil, the prevalence of myopia in indigenous people was reported to be $2.3 \%$ in the right eye (RE), 3.1\% in the left eye (LE), and $1.6 \%$ bilateral. ${ }^{35}$ In Mexico, the studies have assessed the prevalence of myopia only in urban areas. ${ }^{36-39}$ Moreover, some of these studies cannot be compared due to the definitions of refractive errors used. ${ }^{36,37}$ In 2003, Villarreal et al ${ }^{38}$ studied 1,035 children between 12 and 13 years of age in Monterrey, Mexico, and reported a prevalence of myopia of $44 \%$ (SE $\leq-0.50 \mathrm{D})$, hyperopia of $6 \%(\mathrm{SE} \geq+1.00 \mathrm{D})$, and astigmatism of $9.5 \%$ (cylinder $\leq-1.50 \mathrm{D})$. 
In 2007, Rodríguez-Ábrego and Sotelo-Dueñas ${ }^{39}$ studied 1,136 children between 6 and 15 years of age in the City of Nezahualcoyotl, State of Mexico, and reported a prevalence of myopia ( $\mathrm{SE} \leq-0.50 \mathrm{D})$ of $33 \%$; nevertheless, in this study, the diagnosis of refractive state was determined without cycloplegic agents. The current study focused on improving the available information on the prevalence of myopia in rural areas.

\section{Methods}

A cross-sectional study was conducted in the community of San Juan Teacalco, Temascalapa, State of Mexico, which has 2,970 inhabitants, ${ }^{40}$ whose main economic activities are agriculture and animal husbandry. There are three schools (two elementary and one secondary), and one communitarian health center led by a physician and a nurse. Optometrical and ophthalmological examinations are not undertaken at this communitarian health center. A total of 317 out of 339 schoolchildren (22 kids were excluded because they did not attend the class at the day of our examination) between 6 and 12 years old (mean \pm standard deviation [SD] of $8.66 \pm 1.90$ years) were examined at the elementary schools of Ignacio Zaragoza $(n=175)$ and General Francisco Villa $(n=142)$. Of these children, $44.8 \%$ were girls and 55.2\% were boys. Three optometrists from Instituto Politecnico Nacional carried out refractive diagnosis in the following two stages:

1) Screening: a survey was conducted to collect the following data: visual acuity at $3 \mathrm{~m}$ with the Snellen chart, personal data, the use of glasses, family history of the use of glasses, and symptoms and examination of eye adnexa. Children who had any ocular pathology or those whose parents failed to sign an informed consent form were excluded.

2) Refractive diagnosis: refractive examination was performed using static retinoscopy without cycloplegic agents. The bichromatic and Jackson cross cylinder subjective tests were applied, too.

The study was approved by College of Professors of the Interdisciplinary Center for Health Science from Instituto Politecnico Nacional. All procedures were conducted according to the Declaration of Helsinki. Written informed consent was obtained from the parents of the children. Statistical analysis was performed using the statistical software SPSS 23 (IBM, SPSS, Statistics 23).

\section{Results}

Figure 1 shows the distribution of the mean SE of both eyes.

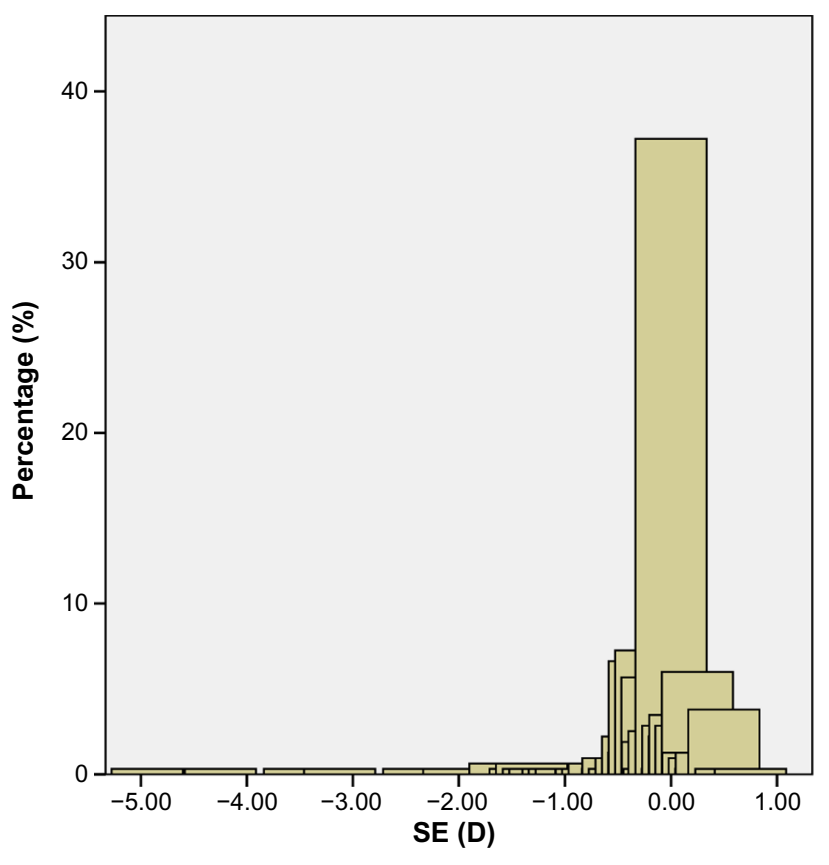

Figure I Distribution of the mean SE of both eyes. Abbreviation: SE, spherical equivalent.

The SE of the right eye (RE), with a mean \pm SD of $-0.1183 \pm 0.567 \mathrm{D}$, was compared with that of the left eye (LE), with a mean \pm SD of $-0.1075 \pm 0.629$ D.

Myopia in at least one eye or bilaterally was the main refractive error, with a prevalence of $9.7 \%$ or $6.6 \%$, respectively, as shown in Table 1.

In the entire sample, $7.9 \%$ reported a family history of some type of refractive error, and 5.4\% wore glasses.

The risk factors for myopia were analyzed using Fisher's exact test and logistic regression analysis, as shown in Table 2. The control group comprised children who are not shortsighted. We found that the prevalence of myopia was higher in males (10.3\%). In addition, $16.1 \%$ of the myopic patients reported a family history of wearing glasses, and $22.6 \%$ wore glasses themselves.

Table I The prevalence of refractive errors

\begin{tabular}{llll}
\hline $\begin{array}{l}\text { Refractive } \\
\text { error }\end{array}$ & Definition & Percentage & $\mathbf{9 5 \%} \mathbf{C l}$ \\
\hline Myopia & $\begin{array}{l}\text { SE } \leq-0.50 \mathrm{D} \text { in at least } \\
\text { one eye }\end{array}$ & 9.8 & $13.07-6.52$ \\
Myopia & SE $\leq-0.50 \mathrm{D}$ bilateral & 6.6 & $9.33-3.87$ \\
Hyperopia & SE $\geq+0.50 \mathrm{D}$ in at least & 5.4 & $7.89-2.91$ \\
Astigmatism & $\begin{array}{l}\text { Cylinder } \leq-I .50 \mathrm{D} \text { in at } \\
\text { least one eye }\end{array}$ & 4.4 & $6.66-2.14$ \\
Astigmatism & Cylinder $\leq-$ I.50 D bilateral & 2.2 & $3.8 \mathrm{I}-0.58$ \\
\hline
\end{tabular}

Abbreviations: $\mathrm{Cl}$, confidence interval; SE, spherical equivalent. 
Table 2 The risk factors for myopia

\begin{tabular}{|c|c|c|c|c|}
\hline Factors & Cases & Controls & $P$-value & OR $(95 \% \mathrm{Cl})$ \\
\hline \multicolumn{5}{|l|}{ Sex } \\
\hline Female & 13 & 129 & 0.850 & I.I38 (0.537-2.410) \\
\hline Male & 18 & 157 & & \\
\hline \multicolumn{5}{|c|}{ Father, mother, or both wear glasses } \\
\hline Yes & 5 & 20 & 0.083 & $2.558(0.887-7.379)$ \\
\hline No & 26 & 266 & & \\
\hline \multicolumn{5}{|c|}{ Use of glasses } \\
\hline Yes & 7 & 10 & 0.00042 & $8.05(2.81 \mathrm{I}-23.052)$ \\
\hline No & 24 & 276 & & \\
\hline
\end{tabular}

Abbreviations: $\mathrm{OR}$, odds ratio; $\mathrm{Cl}$, confidence interval.

\section{Discussion}

In our study, the prevalence of myopia was $9.8 \%$, which is lower than that reported in studies performed in urban areas by Villarreal et al (44\%) ${ }^{38}$ and Rodríguez-Ábrego and SoteloDueñas $(33 \%))^{39}$ Furthermore, it is possible that the prevalence of myopia found in our study and Rodríguez-Ábrego and Sotelo-Dueñas's ${ }^{39}$ study may be lower because of an overestimation due to the lack of cycloplegic agents for the determination of refractive errors. ${ }^{41-43}$ However, our results are consistent with the studies performed in the People's Republic of China and India, where a lower prevalence of myopia in rural areas was found than that in urban areas..$^{30-33}$

Among myopic patients, $22.6 \%$ wore glasses, which is a larger percentage than that previously reported by Villarreal et al $(17 \%)^{38}$ and Rodríguez-Ábrego and Sotelo-Dueñas $(17.6 \%)^{39}$ in urban areas. However, our results are consistent with the findings of Castanon et $\mathrm{al}^{44}{ }^{44}$ in which a higher frequency in the use of eyeglasses was observed among younger children in rural areas (odds ratio $[\mathrm{OR}]=10.6 ; 95 \%$ confidence interval [CI]: 5.3-21.0). Additionally, a significant difference was found in this study $(P=0.00042$ and $\mathrm{OR}=8.05$; 95\% CI: 2.81-23.05) for nonmyopic subjects.

In our study, $16.1 \%$ of the myopic subjects had a family history with this condition, which was slightly significantly different $(P=0.083$ and $\mathrm{OR}=2.558$; 95\% CI: 0.887-7.379) compared to nonmyopic subjects. In contrast, RodríguezÁbrego and Sotelo-Dueñas ${ }^{39}$ found significant differences ( $P=0.001$ and $\mathrm{OR}=1.62 ; 95 \% \mathrm{CI}: 1.22-2.14)$, although this difference may have been due to sample size variation across studies and the area where the study was realized.

Villarreal et $\mathrm{a}^{38}$ and Rodríguez-Ábrego and SoteloDueñas $^{39}$ reported a significant difference in the prevalence of myopia according to sex, being women the most affected. In contrast, we observed a higher percentage of myopic males $(10.3 \%)$ than females $(9.15 \%)$, although this difference was not significant $(P=0.850)$.
The prevalence of hyperopia (5.4\%) and astigmatism $(4.4 \%)$ was also lower than what has been reported previously by Villarreal et al. ${ }^{38}$ The low prevalence of hyperopia and astigmatism may have been due to the lack of use of cycloplegic agents for determining the refractive diagnosis..$^{40-43}$

We are conscious about the induced inaccuracy in assessing the prevalence of refractive errors due to the fact that we did not use cycloplegic agents. However, we considered that the clinical diagnosis, and hence the prescription of eyeglasses, should be on the basis of a more realistic setting for our children, who exert a latent accommodation in ordinary situations, as reported elsewhere. ${ }^{43}$

\section{Conclusion}

Although the prevalence of myopia and other refractive errors is low, it is important to conduct further research to assess the prevalence of refractive errors in rural areas, to analyze the associated risk factors, and to implement visual health plans, both informational and corrective, with the aim of improving the quality of vision in the rural population.

\section{Acknowledgment}

The authors thank Instituto Poltecnico Nacionacial by project support SIP: 20144402.

\section{Author contributions}

All authors contributed toward data analysis, drafting and critically revising the paper and agree to be accountable for all aspects of the work.

\section{Disclosure}

The authors report no conflicts of interest in this work.

\section{References}

1. Norton TT, Manny R, O`Leary DJ. Myopia - a global problem, global research. Optom Vis Sci. 2005;82(4):223-225.

2. Park DJ, Congdon NG. Evidence for "epidemic" of myopia. Ann Acad Med Singapore. 2004;33(1):21-26.

3. Charman N. Myopia: its prevalence, origins and control. Ophthalmic Physiol Opt. 2011;31(1):3-6.

4. Pan CW, Ramamurthy D, Saw SM. Worldwide prevalence and risk factors for myopia. Ophthalmic Physiol Opt. 2012;32(1):3-16.

5. Pan CW, Wong TY, Lavanya R, et al. Prevalence and risk factors for refractive errors in Indians: the Singapore Indian Eye Study (SINDI). Invest Ophthalmol Vis Sci. 2011;52(6):3166-3173.

6. Gilmartin B. Myopia precedents for research in the twenty-first century. Clin Experiment Ophthalmol. 2004;32(3):305-324.

7. Shah SP, Jadoon MZ, Dineen B, et al; Pakistan National Eye Survey Study Group. Refractive errors in the adult Pakistani population: the national blindness and visual impairment survey. Ophthalmic Epidemiol. 2008;15(3):183-190. 
8. Sawada A, Tomidokoro A, Araie M, Iwase A, Yamamoto T. Refractive errors in an elderly Japanese population: the Tajimi study. Ophthalmology. 2008;115(2):363-370.

9. Krishnaiah S, Srinivas M, Khanna RC, Rao GN. Prevalence and risk factors for refractive errors in the South Indian adult population: the Andhra Pradesh Eye disease study. Clin Ophthalmol. 2009;3:17-27.

10. Saw SM, Chan YH, Wong WL, et al. Prevalence and risk factors for refractive errors in the Singapore Malay Eye Survey. Ophthalmology. 2008;115(10):1713-1719.

11. Czepita D, Zejmo M, Artur Mojsa A. Prevalence of myopia and hyperopia in a population of Polish schoolchildren. Ophthalmic Physiol Opt. 2007;27:60-65.

12. O’Donoghue L, McClelland JF, Logan NS, Rudnicka AR, Owen CG, Saunders KJ. Refractive error and visual impairment in school children in Northern Ireland. Br J Ophthalmol. 2010;94(9):1155-1159.

13. Fan DS, Lam DS, Lam RF, et al. Prevalence, incidence, and progression of myopia of school children in Hong Kong. Invest Ophthalmol Vis Sci. 2004;45(4):1071-1075.

14. Vitale S, Sperduto RS, Ferris FL 3rd. Increased prevalence of myopia in the United States between 1971-1972 and 1999-2004. Arch Ophthalmol. 2009;127(12):1632-1639.

15. Hyman L, Gwiazda J, Hussein M, et al; COMET Study Group. Relationship of age, sex, and ethnicity with myopia progression and axial elongation in the correction of myopia evaluation trial. Arch Ophthalmol. 2005;123(7):977-987.

16. Rose KA, Morgan IG, Ip J, et al. Outdoor Activity Reduces the Prevalence of Myopia in Children. Ophthalmology. 2008;115(8):1279-1285.

17. Rose KA, Morgan IG, Smith W, Burlutsky G, Mitchell P, Saw SM. Myopia, lifestyle, and schooling in students of Chinese ethnicity in Singapore and Sydney. Arch Ophthalmol. 2008;126(4):527-530.

18. Hornbeak DM, Young TL. Myopia genetics: a review of current research and emerging trends. Curr Opin Ophthalmol. 2009;20(5):356-362.

19. Young TL. The molecular genetics of human myopia: an update. Optom Vis Sci. 2009;86(1):E8-E22.

20. Wojciechowski R. Nature and nurture: the complex genetics of myopia and refractive error. Clin Genet. 2011;79(4):301-320.

21. Saw SM. A synopsis of the prevalence rates and environmental risk factors for myopia. Clin Exp Optom. 2003;86(5):289-294.

22. Robinson BE. Factors associated with the prevalence of myopia in 6-year-olds. Optom Vis Sci. 1999;76(5):266-271.

23. Saw SM, Chua WH, Hong CY, et al. Near work in early onset myopia. Invest Ophthalmol Vis Sci. 2002;43(2):332-339.

24. Mutti DO, Mitchell GL, Moeschberger ML, Jones LA, Zadnik K. Parental myopia, near work, school achievement, and children's refractive error. Invest Ophthalmol Vis Sci. 2002;43(12):3633-3640.

25. Ip JM, Saw SM, Rose KA, et al. Role of near work in myopia: findings in a sample of Australian school children. Invest Ophthalmol Vis Sci. 2008;49(7):2903-2910.

26. Lu B, Congdon N, Liu X, et al. Associations between near work, outdoor activity, and myopia among adolescent students in rural China: the Xichang Pediatric Refractive Error Study report no. 2. Arch Ophthalmol. 2009;127(6):769-775.
27. Mehdizadeh M, Nowroozzadeh MH. Outdoor activity and myopia. Ophthalmology. 2009;116(6):1229-1230.

28. Rose KA, Morgan IG, Ip J, et al. Outdoor activity reduces the prevalence of myopia in children. Ophthalmology. 2008;115(8):1279-1285.

29. Dirani M, Tong L, Gazzard G, et al. Outdoor activity and myopia in Singapore teenage children. Br J Ophthalmol. 2009;93:997-1000.

30. He M, Zheng Y, Xiang F. Prevalence of myopia in urban and rural children in mainland China. Optom Vis Sci. 2009;86(1):40-44.

31. Garner LF, Owens H, Kinnear RF, Frith MJ. Prevalence of myopia in Sherpa and Tibetan children in Nepal. Optom Vis Sci. 1999;76(5): 282-285.

32. Xu L, Li J, Cui T, et al. Refractive error in urban and rural adult Chinese in Beijing. Ophthalmology. 2005;112(10):1676-1683.

33. Ip JM, Rose KA, Morgan IG, Burlutsky G, Mitchell P. Myopia and the urban environment: findings in a sample of 12-year-old Australian school children. Invest Ophthalmol Vis Sci. 2008;49(9):3858-3863.

34. Tarczy-Hornoch K, Ying-Lai M, Varma R; Los Angeles Eye Study Group. Myopic refractive error in adults latinos: the Los Angeles Eye Study. Invest Ophthalmol Vis Sci. 2006;47(5):1845-1852.

35. Thorn F, Cruz A, Machado A, Carvalho R. Refractive status of indigenous people in the northwestern Amazon region of Brazil. Optom Vis Sci. 2005;82(4):267-272.

36. Baz-Iglesias R, Solís-López S, Gaxiola-Armenta M, Carrillo-Gómez S, Baz-Díaz Lombardo G. Las alteraciones visuales en el municipio de Naucalpan [Visual disturbances in the municipality of Naucalpan]. Salud Pública Méx. 1984;26(1):17-25.

37. Ramírez-Sánchez EV, Arroyo ME, Magaña M. Determinación del estado refractivo en niños sanos, en el Hospital General de México. [Determination of refractive status in healthy children in Mexico General Hospital]. Rev Mex Oftalmol 2003;77(3):120-123.

38. Villarreal GM, Ohlsson J, Cavazos H, Abrahamsson M, Mohamed JH. Prevalence of myopia among 12- to 13-year-old schoolchildren in northern Mexico. Optom Vis Sci. 2003;80(5):369-373.

39. Rodríguez-Ábrego G, Sotelo-Dueñas HM. Prevalencia de miopía en escolares de una zona suburbana [Prevalence of myopia among schoolchildren in a suburban area]. Rev Med Inst Mex Seguro Soc. 2009;47(1):39-44.

40. Instituto Nacional de Geografía y Estadística (INEGI), Censo Nacional de Población y vivienda: 2010. Available from: www3.inegi.org/ sistemas/iter/consultar_info.aspx. Accessed March 8, 2016.

41. Chan O, Edwards M. Comparison of cycloplegic and noncycloplegic retinoscopy in Chinese pre-school children. Optom Vis Sci. 1994;71(5):312-318.

42. Jorge J, Queiros A, González-Méijome J, Fernandes P, Almeida JB, Parafita MA. The influence of cycloplegia in objective refraction. Ophthalmic Physiol Opt. 2005;25(4):340-345.

43. Junghans BM, Crewther SG. Prevalence of myopia among primary school children in eastern Sydney. Clin Exp Optom. 2003;86(5):339-345.

44. Castanon AM, Congdon N, Patel N, et al. Factors associated with spectacle-wear compliance in school-aged Mexican children. Invest Ophthalmol Vis Sci. 2006;47(3):925-928.
Clinical Optometry

\section{Publish your work in this journal}

Clinical Optometry is an international, peer-reviewed, open access journal publishing original research, basic science, clinical and epidemiological studies, reviews and evaluations on clinical optometry. All aspects of patient care are addressed within the journal as well as the practice of optometry including economic and business analyses. Basic and clinical Submit your manuscript here: http://www.dovepress.com/clinical-optometry-journal
Dovepress

research papers are published that cover all aspects of optics, refraction and its application to the theory and practice of optometry. The manuscript management system is completely online and includes a very quick and fair peer-review system, which is all easy to use. Visit http://www.dovepress. com/testimonials.php to read real quotes from published authors. 